\title{
Biological Pretreatment of Corn Stover for Enhancing Enzymatic Hydrolysis Using Thermoalkalotolerant Cellulolytic Enzymes Produced by Bacillus sp. P3
}

\section{Yanwen Wu}

Co-innovation Center for Sustainable Forestry in Southern China, Jiangsu Province Key Laboratory of Soil and Water Conservation and Ecological Restoration, Nanjing Forestry University, Nanjing 210037, China

\section{Haipeng Guo}

School of Marine Sciences, Ningbo University, Ningbo 315211, China

\section{Md. Shafiqur Rahman}

Department of Biology, Lakehead university, Canada

\section{Xuantong Chen}

Department of Biology, Lakehead University, Thunder Bay, ON P7B 5E1, Canada

\section{Jinchi Zhang}

Co-innovation Center for Sustainable Forestry in Southern China, Jiangsu Province Key Laboratory of Soil and Water Conservation and Ecological Restoration, Nanjing Forestry University, Nanjing 210037, China

\section{Yun Liu}

Beijing Key Laboratory of Bioprocess, College of Life Science and Technology, Beijing University of Chemical Technology, Beijing 100029, China

Wensheng Qin ( $\triangle$ wqin@lakeheadu.ca )

Lakehead University https://orcid.org/0000-0003-2178-4003

\section{Research}

Keywords: Bacillus sp. P3, biological pretreatment, corn stover, enzymatic hydrolysis, thermoalkalotolerant enzymes

Posted Date: July 9th, 2021

DOl: https://doi.org/10.21203/rs.3.rs-665509/v1

License: (c) (1) This work is licensed under a Creative Commons Attribution 4.0 International License. Read Full License 
Page $2 / 22$ 


\section{Abstract}

The biological pretreatment for the enzymatic hydrolysis of lignocellulosic biomasses largely depends on an effective pretreatment process. A significant enhancement of enzymatic saccharification was obtained with corn stover using Bacillus sp. P3. The hemicellulose removal from corn stover by the strain Bacillus sp. P3 was evaluated for enhancing subsequent enzymatic hydrolysis. Therefore, our study revealed that an alkaline resistant xylanase produced by Bacillus sp. P3 in fermentation broth led to a substantially enhanced hemicellulose removal rate from corn stover within $\mathrm{pH}$ 9.36-9.68. However, after $20 \mathrm{~d}$ pretreatment of corn stover by the strain P3, the glucan content was increased by $51 \%$ and the xylan content was decreased by $35 \%$. After $72 \mathrm{~h}$ of saccharification using $20 \mathrm{U} \mathrm{g}^{-1}$ of commercial cellulase, the yield of reducing sugar released from $20 \mathrm{~d}$ pretreated corn stover was increased by $56 \%$ in comparison to the untreated corn stover. Therefore, the use of the strain P3 could be a promising approach to pretreat corn stover for enhancing the enzymatic hydrolysis process of industrial bioenergy productions.

\section{Introduction}

Increasing consumption of fossil fuel has resulted in an increase in fuel cost and atmospheric greenhouse gas emission, thus, the raw materials for fuel production are gradually replacing by renewable bioresources. Lignocellulosic biomasses from agricultural residues are great potential resource for biofuel production due to their wide distribution, abundant reserve, low price, and renewability (Wan and Li 2010). Therefore, the utilization of these lignocellulosic biomasses to produce biofuels has become an interesting research field. However, various obstacles associated with the current methods of biofuel production using lignocellulosic biomasses still need to be overcome. One of the key problems hampering the bioconversion of agricultural residues is the high resistance of lignocellulose to hydrolysis, which is caused by the recalcitrant crystalline structure of cellulose fibrils surrounded by hemicelluloses and further sealed by lignin (Himmel et al. 2007), thus, the effective pretreatment processes are necessary to enhance the hydrolysis rate and separate hemicellulose from cellulose that allow the access of hydrolytic enzymes and increase the sugar yield (Zhao et al. 2012; Kumar et al. 2009).

Currently practicing chemical pretreatment methods including steam explosion, dilute acid extraction, wet oxidation, and soaking in aqueous ammonia (SAA) for efficient degradation of hemicellulose require expensive instruments and high energy consumption (Wang et al. 2013). Furthermore, these chemical pretreatments often result in the generation of inhibitors as well as the production of acidic or alkaline wastewater, which create an environmental issue. Therefore, an eco-friendly biological pretreatment using microorganisms has been considered as an alternative to harsh chemicals and thermochemical pretreatments for lignocellulosic biomass conversion due to its low energy requirement (Keller et al. 2003). The microbial pretreatment involving fungi, especially white, brown, and soft-rot fungi have been widely used to degrade hemicellulose and lignin from lignocellulosic biomasses (Keller et al. 2003). The white rot fungi have been studied as the most effective microbial candidates to pretreat lignocellulosic biomasses (Kirk and Cullen 1998). The reducing sugars released from pretreated lignocellulosic biomasses (wheat straw, rice straw and corn stover) increased 50-65\% enzymatic saccharification 
compared to that of non-pretreated control samples using white-rot fungi (Wang et al. 2013; Bak et al. 2010). Although a wide variety of hydrolytic enzymes (cellulases and hemicellulases) from fungal strains have been applied in the industry (Kirk and Cullen 1998; Pérez et al. 2002), the bacterial strain could be used as a more promising candidate to pretreat the lignocellulosic biomasses due to their tremendous cellulolytic enzyme producing ability which is valuable to degrade the lignocellulose (Lynd et al. 2002). Moreover, compare to fungi, bacteria have the following advantages (Sangrila and Mait 2013): (1) bacteria have a higher growth rate to accelerate the production of enzymes; (2) bacteria can produce more complex glycoside hydrolases which have the potential to provide synergistic functions; (3) bacterial strains are excellent at resisting environmental stresses. Although the optimal $\mathrm{pH}$ values of the fungal culture for maximum cellulase production are slightly acidic ranges from 4.8 to 6.0 (Chang and Steinkraus 1982), the optimal $\mathrm{pH}$ values of the most cellulolytic enzyme-producing bacteria are in a range from 8.0 to 9.5 (Liu et al. 2017), thereby, the degradation efficiency of lignocellulosic biomass is decreasing due to low enzyme activities at unsuitable pH values (Maki et al. 2009). This problem severely hinders the direct application of cellulolytic enzymes producing bacteria to pretreat the lignocellulosic biomasses for biofuels production. Consequently, to improve the biomass degradation efficiency, it is necessary to find some alkali-tolerant cellulolytic enzymes from bacterial candidate.

Therefore, our study was focused on an alkali-tolerant cellulolytic enzyme producing Bacillus sp. P3 strain to explore the feasibility of pretreatment for the degradation ability and enzymatic productivity using various lignocellulosic materials. The lignocellulosic material that induced maximum enzyme production was selected as the carbon source to optimize the enzyme production conditions. Under optimal conditions, the strain P3 was directly cultured with the selected lignocellulosic material to weaken its structure mainly by decomposing hemicellulose. The effect of pretreatment was then assessed by reducing sugar yields from the pretreated materials in enzymatic saccharification with commercial cellulase.

\section{Materials And Methods}

\section{Corn stover and bacterial strain P3}

Corn stover was provided by Agriculture and Agri-Food Canada. The air-dried corn stover was chopped and milled to pass through a 50-mesh sieve for this study. The milled sample was stored at ambient temperature in an airtight container until use.

The Bacillus sp. strain P3 (accession No. MF462257) and its enzymatic characteristics have been described previously (Guo et al. 2017a). The strain P3 was stored at $-70^{\circ} \mathrm{C}$ and activated by culturing in Luria-Bertani (LB) broth (10 g/L peptone, $5 \mathrm{~g} / \mathrm{L}$ yeast extract, $10 \mathrm{~g} / \mathrm{L} \mathrm{NaCl})$ medium at $37^{\circ} \mathrm{C}$ and $200 \mathrm{rpm}$ for $12 \mathrm{~h}$ as a seed culture of fermentation experiments.

\section{Evaluations of biomass degradation abilities}


To assess the biomass degradation ability of the strain P3, different lignocellulosic biomasses including agave, algae, corn stover, Miscanthus, wheat bran, wood dust and pine chip were used as the carbon sources according to the method described by Guo et al. (2017b). Briefly, a $5.0 \mu$ of the overnight grown LB broth culture was dropped or inoculated on the plate containing modified minimal salt (MMS) medium $\left(0.1 \% \mathrm{NaNO}_{3}, 0.1 \% \mathrm{~K}_{2} \mathrm{HPO}_{4}, 0.1 \% \mathrm{KCl}, 0.05 \% \mathrm{MgSO}_{4}, 0.05 \%\right.$ yeast and $0.3 \%$ peptone) supplemented with $1.5 \%$ agar and $0.5 \%$ biomass or $\mathrm{CMC}$ or xylan, incubated at $37^{\circ} \mathrm{C}$ for $48 \mathrm{~h}$. The biomass degradation ability was evaluated based on the size of biomass hydrolyzing zone (zone of clearance or halo zone) produced on the plate by the bacterial strain after staining with Gram's iodine solution.

\section{Optimization of fermentation parameters for cellulolytic enzyme production}

To optimize the fermentation conditions for maximum enzyme production, the strain P3 was inoculated $(2 \%, \mathrm{v} / \mathrm{v})$ in the MMS broth medium supplemented with $0.5 \%(\mathrm{w} / \mathrm{v})$ biomass or $\mathrm{CMC}$, incubated at desired temperature for desired time in a rotary shaker incubator of $200 \mathrm{rpm}$. To evaluate the influence of different carbon sources on enzyme production, the agave, algae, corn stover, Miscanthus, wheat bran, wood dust, pine chip and $\mathrm{CMC}$ were used as the substrates according to the method described previously (Guo et al. 2017b). Following incubation, the broth culture was centrifuged at $12000 \mathrm{~g}$ for 3 min to obtain the supernatant, which was used as the crude enzymes for CMCase and xylanase activities analysis. The activities of CMCase and xylanase were determined by measuring the released reducing sugar from substrate. The reducing sugar content was measured by DNS method (Miller 1959). The substrate corn stover (carbon source) was selected to optimize the biomass concentrations for lignocellulosic enzymes production due to its high CMCase and xylanase production ability compared with other biomasses tested herein. For optimization of corn stover concentrations, the MMS broth medium was supplemented with $0.5 \%, 1.0 \%, 2.0 \%$ and $4.0 \%$ corn stover, respectively.

The influences of temperature on CMCase and xylanase productions were investigated by culturing the strain P3 at $30,37,45$ and $50^{\circ} \mathrm{C}$ for $24 \mathrm{~h}$, while the effects of different initial pH values of the culture medium on enzyme productions were determined in a wide range of $\mathrm{pH}$ from 5.0 to 10.0 at an interval of 0.5. The $\mathrm{pH}$ values of medium were adjusted with the addition of hydrochloric acid $(\mathrm{HCl})$ and sodium hydroxide $(\mathrm{NaOH})$.

\section{Effects of temperature and pH on enzyme activities}

The crude enzymes harvested under optimal fermentation conditions were taken for evaluating the effects of temperature and $\mathrm{pH}$ on $\mathrm{CMCase}$ and xylanase activities. However, for determining the effects of incubation temperature and $\mathrm{pH}$ of the reaction mixtures with crude enzyme, a wide range of temperatures from 40 to $80^{\circ} \mathrm{C}$ and $\mathrm{pH}$ from 4.0 to 9.5 were set the incubation periods. The $0.05 \mathrm{M}$ citrate and Tris- $\mathrm{HCl}$ buffer solutions were used respectively to set the $\mathrm{pH}$ of the enzyme reaction mixtures.

\section{Bacterial pretreatment of corn stover}


For bacterial pretreatment, dried corn stover $(0.5 \%, \mathrm{w} / \mathrm{v})$ was mixed with MMS broth medium, autoclaved at $121^{\circ} \mathrm{C}$ for $30 \mathrm{~min}$. An overnight LB broth culture of the strain P3 was inoculated $(2 \%, \mathrm{v} / \mathrm{v})$ in an Erlenmeyer flask containing $50 \mathrm{ml}$ of medium. A control flask of $50 \mathrm{ml}$ medium without bacterial inoculum was also maintained. Bacterial pretreatment was performed at $37^{\circ} \mathrm{C}$ with $200 \mathrm{rpm}$ for $20 \mathrm{~d}$, and all flasks were covered by parafilm to prevent water evaporation in this process (Papavizas et al. 1984). The samples were taken 5-10 d intervals, filtered through a double layered muslin cloth (300 mesh) and the supernatant was collected for the determination of reducing sugar as well as enzymes (CMCase and xylanase) activities. The residue was washed several times with distilled water through a double layered muslin cloth (300 mesh) to remove the bacterial cells, dried at $50^{\circ} \mathrm{C}$ until constant weight and used to determine the weight loss and cell wall compositions. The $\mathrm{pH}$, enzyme activities and reducing sugar content of supernatant were determined after centrifugation at $1200 \mathrm{~g}$ for 3 minutes.

\section{Biomass composition analysis}

According to the methods described by Shrestha et al. (2015), the analysis of cellulose and hemicellulose contents was carried out by measuring the contents of glucan and xylan. Anthrone-sulfuric acid and orcinol-hydrochloric acid methods (Leyva et al. 2008; Tomoda 1963) were used to determine the content of hexose and pentose, respectively. The Klason lignin analysis was conducted using the method written by Ibáñez and Bauer (2014).

\section{Enzymatic saccharification of pretreated corn stover}

To detect the saccharification effect of the corn stover pretreated by the strain P3, commercial cellulase extracted from Trichoderma reesei ATCC 26921 (Celluclast 1.5 L, Novozymes, Franklinton, NC, USA) was used. The corn stover samples pretreated for 5,10 and 20 days were saccharified by loading $20 \mathrm{FPU} \mathrm{g}{ }^{-1}$ of commercial cellulase, the amount of which was set at the maximum to sufficiently hydrolyze the substrate according to the previous study (Singh et al. 2009). Enzymatic saccharification was conducted in $0.05 \mathrm{M}$ citrate buffer $(\mathrm{pH} 4.8)$ containing $1 \%(\mathrm{w} / \mathrm{v})$ pretreated corn stover and $0.005 \%$ sodium azide (Ferraz et al. 2017). The reaction mixture was incubated at $50^{\circ} \mathrm{C}$ with an agitation of $200 \mathrm{rpm}$ for $72 \mathrm{~h}$. The non-pretreated corn stover was used as the control group. The reducing sugar was determined using method DNS method (Miller 1959).

\section{Statistical Analysis}

All data in our experiments were obtained from the mean of three replicates. To quantify the significant difference between different treatments, statistical analysis was carried out by one-way analysis of variance. Pearson correlation analysis was conducted to explain the main factor resulting in the release of reducing sugar in enzymatic saccharification. Statistical analysis was performed using SPSS (SPSS Inc., USA, version 13.0).

\section{Results And Discussions}

Biomass degradation ability of Bacillus sp. P3 
Bacillus sp. P3 has the capability of producing cellulolytic enzymes by utilizing various lignocellulosic materials. The biomass hydrolysis ability of the strain P3 was evaluated on the cellulosic biomass or $\mathrm{CMC}$ or xylan containing MMS agar culture plate by staining with Gram's iodine solution (Fig. 1). Gram's iodine produces bluish-black products with cellulose but not with its hydrolysates, therefore, a clear zone produced around the bacterial growth after addition of iodine solution indicates that the organism has hydrolyzed cellulose (Guo et al. 2017b). The strain P3 produced the notable largest clear or halo zones, ranging from 3.09 to $4.02 \mathrm{~cm}$ on the plates by hydrolyzing the biomasses, and the maximum hydrolysis (4.02 cm halo zone) of biomass was detected using corn stover as a carbon source (Fig. 1). Moreover, in our experiment, the clear halo regions on the $\mathrm{CMC}$ and xylan containing plates indicated the hydrolysis of biomasses by CMCase and xylanase enzymes respectively produced from the stain P3, and the results are supported by the result reported previously (Lin et al. 2017). Several studies have been done by other researchers on the capability of producing various extracellular lignocellulolytic enzymes by Bacillus sp. (Wilson 2009; Arantes and Saddler 2010), and the enzymes exhibited outstanding hydrolytic ability to various lignocellulosic feedstocks (Alvira et al. 2010).

\section{Optimization of culture conditions for cellulolytic enzymes production}

\section{Substrates and its concentrations for maximum cellulolytic enzymes production}

Therefore, for selecting the best substrate (carbon source) to induce the production of cellulolytic enzymes, eight typical lignocellulosic biomasses viz., agave, algae, corn stover, Miscanthus, wheat bran, wood dust, pine chip and CMC were used for cellulolytic enzyme production by the strain Bacillus sp. P3. The maximum CMCase activity with the value of $17.81 \mathrm{U} \mathrm{g}^{-1}$ was obtained using $0.5 \%(\mathrm{w} / \mathrm{v})$ corn stover after $36 \mathrm{~h}$ of cultivation, while the highest CMCase activities ranged from 4.23 to $14.57 \mathrm{U} \mathrm{g}^{-1}$ were obtained using other carbon sources (Fig. 2A). In addition, the maximum xylanase activities were 214.41, 213.59 and $195.85 \mathrm{U} \mathrm{g}^{-1}$ using wheat bran, algae and corn stover as the carbon sources after $24 \mathrm{~h}, 36 \mathrm{~h}$ and $48 \mathrm{~h}$ of fermentation, respectively (Fig. 2B). The CMCase and xylanase produced from Bacillus sp. strains can be highly induced by the various lignocellulosic biomasses, the main components of which are cellulose, hemicellulose and lignin (Maki et al. 2009; Sadhu et al. 2013). The maximum CMCase activity of the strain P3 was induced by corn stover, which is similar with the results obtained using Bacillus subtilis (Akhtar et al. 2001). Moreover, in this study, the highest xylanase activity (195.85 $\mathrm{U} \mathrm{g}^{-1}$ ) exhibited by the strain P3 using corn stover as a carbon source was significantly higher than that of Bacillus licheniformis A99 $\left(16.30 \mathrm{U} \mathrm{g}^{-1}\right)$ induced by wheat bran under optimal fermentation conditions (Archana et al. 1997). Therefore, the untreated corn stover was selected as a potential lignocellulosic biomass to perform pretreatment experiments due to its easy degradation and high cellulolytic enzymes production by $\mathrm{P} 3$. 
The effects of different concentrations of untreated corn stover on cellulolytic enzymes production were investigated by adding $0.5 \%, 1.0 \%, 2.0 \%$ or $4.0 \%(\mathrm{w} / \mathrm{v})$ of corn stover in the MMS broth medium. The maximum CMCase $\left(12.86 \mathrm{U} \mathrm{g}^{-1}\right)$ and xylanase $\left(214.41 \mathrm{U} \mathrm{g}^{-1}\right)$ produced by the strain $\mathrm{P} 3$ using $0.5 \%$ corn stover were remarkably higher than the results achieved with other three concentrations after $36 \mathrm{~h}$ and 24 $\mathrm{h}$ of fermentation, respectively (Fig. 3). The same substrate concentration (0.5\%, w/v) to produce cellulolytic enzymes by Bacillus sp. strains has been reported earlier (Guo et al. 2017b). Moreover, the activities of CMCase and xylanase were significantly decreased with increasing substrate concentrations. Specifically, the CMCase and xylanase activities obtained with $0.5 \%$ corn stover were increased dramatically (Fig. 3). The excessive biomass content may enhance oxygen transfer in the fermentation broth, which inhibited the cell growth and enzymatic secretion of bacteria (Guo et al., 2017a). In addition, the high concentrations of several hydrolysates (mannose, xylose, and galactose) produced in the process of cellulosic hydrolysis may also be the reason for restraining the activities of cellulolytic enzymes (Xiao et al. 2004).

\section{Optimization of incubation temperature and medium initial $\mathrm{pH}$ for maximum enzyme production}

To optimize the medium initial $\mathrm{pH}$ and fermentation temperature for maximum production of cellulolytic enzymes, the strain P3 was cultured in the MMS broth medium supplemented with $0.5 \%$ corn stover for $24 \mathrm{~h}$ (Fig. S1). The optimal temperature of the strain P3 for producing maximum CMCase and xylanase was $37^{\circ} \mathrm{C}$, and the enzyme production was decreased drastically after reached the peak (Fig. S1A). These results were consistent with an earlier study indicating the optimal temperature of bacterial growth and metabolism was around $37^{\circ} \mathrm{C}$ (Huser et al. 1982). Nevertheless, the strain P3 showed the maximum productions of enzymes at an initial pH 7.0, however, more than $60 \%$ relative enzyme activities were observed when the medium initial pH ranged from 7.5 to 10.0 (Fig. S1B). Moreover, the strain P3 exhibited more than $90 \%$ relative xylanase activity at the initial pH ranging from 9.0 to 10.0 , where the highest relative activity of xylanase was obtained at pH 10.0 (Fig. S1B). Therefore, our results obtained from Bacillus sp. P3 strain were supported by other Bacillus sp. strains, which grew and produce xylanases in a wide range of $\mathrm{pH}$ (6.0-10.0) (Bansod et al. 1993; Annamalai 2014).

\section{Optimization of temperature and $\mathrm{pH}$ for maximum enzyme activities}

Effects of temperature on the activities of CMCase and xylanase obtained from the strain P3 were assessed at different temperatures ranged between 40 and $80^{\circ} \mathrm{C}$ (Fig. $4 \mathrm{~A}$ ). The optimal temperatures for maximum CMCase and xylanase activity were found at 70 and $60^{\circ} \mathrm{C}$, respectively, and both two enzymes exhibited more than $60 \%$ relative activity with slightly declined after reached the peak value (Fig. 4A). These results presented in Fig. 4A were higher than the optimal temperatures of several thermotolerant cellulolytic enzymes produced by the typical Bacillus strains (Kom et al. 2009; Annamalai et al. 2011). Nevertheless, the effects of $\mathrm{pH}$ on $\mathrm{CMCase}$ and xylanase activities were evaluated using different $\mathrm{pH}$ in enzyme reaction mixtures (Fig. 4B). The optimal pH for maximum CMCase activity was recorded as 8.5, 
and more than $75 \%$ relative activity was attained between $\mathrm{pH} 6.0$ and 9.5 . Therefore, in case of xylanase, the maximum activity was obtained at a pH 6.0 , and more than $70 \%$ relative activities were accomplished in alkaline $\mathrm{pH}$ conditions (Fig. 4B). The optimal pH values of two cellulolytic enzymes produced by the strain P3 were significantly higher than that of cellulases and xylanases produced by other Bacillus sp. strains (Kim et al. 2009; Lee et al. 2008), indicating that cellulolytic enzymes produced by strain P3 were alkalotolerant.

According to earlier study, lignocellulose deconstructing enzymes (cellulases and hemicellulases) could be used to pretreat lignocellulosic biomass for biofuel production, and the production methods are normally conducted at high temperature $\left(\geq 50^{\circ} \mathrm{C}\right)$ with alkaline conditions to increase the reaction velocities of enzymatic hydrolysis and yields of reducing sugar (Bhalla et al. 2013). Therefore, the application of thermotolerant and alkalotolerant cellulolytic enzymes to high temperature and alkaline environments was put forward as an efficient approach to overcome these limitations (Yeoman et al. 2010). It is widely accepted that bacteria are one of the most efficient producers of thermoalkalotolerant cellulases and xylanases (Saratale and Oh 2011). Several scholars have been tried to isolate potential bacterial candidates for the production of these thermotolerant and alkaliphilic cellulolytic enzymes due to their enormous industrial potential (Maki et al. 2009). Meanwhile, overmuch cellulase would contribute to the loss of cellulose for subsequent saccharification, therefore, the strong hydrolytic ability mainly caused by high xylanase activity of a bacterial strain is applicable in bio-pretreatment for selective removal of hemicellulose from lignocellulosic biomass (Kohli et al. 2001). In this study, the strain Bacillus sp. P3 had the capability of withstanding extreme conditions of thermal and high pH and exhibited 16.67fold higher activity of xylanase compared to that of CMCase in the optimal cultivation condition (Fig. 3). Hence, the strain P3 and its cellulolytic enzymes could be used as the potential candidates for harsh production applications.

\section{Characterization of fermented supernatants and corn stover before and after pretreatments}

\section{The pH values, cellulolytic enzyme activities and reducing sugar yields}

The $\mathrm{pH}$ value of the fermentation broth notably increased from neutral (initial $\mathrm{pH} 7.0$ ) to high alkaline (9.41) after $5 \mathrm{~d}$ cultivation of the strain $\mathrm{P} 3$ and the high $\mathrm{pH}$ condition (9.36-9.68) was observed until end of this experiment (Table 1). Most of the Bacillus sp. strains have been proven the capability of changing surrounding habitats to be alkaline during the fermentation process due to secretion of secondary metabolites (Schallmey et al. 2004), which could be the main reason to explain the $\mathrm{pH}$ variation in this study. 
Table 1

The $\mathrm{pH}$ values, enzyme activities and reducing sugar yields of the supernatants, as well as the weight losses and compositions of corn stover pretreated with strain P3 for different times $(n=3)$.

\begin{tabular}{|c|c|c|c|c|c|c|c|c|}
\hline \multirow{2}{*}{$\begin{array}{l}\text { Time } \\
\text { (d) }\end{array}$} & \multirow[t]{2}{*}{$\mathrm{pH}$} & \multicolumn{2}{|c|}{ Enzymes $\left(\mathrm{U} \mathrm{g}^{-1}\right)$} & \multirow{2}{*}{$\begin{array}{l}\text { Reducing } \\
\text { sugar (mg g } \\
\text { 1) }\end{array}$} & \multirow{2}{*}{$\begin{array}{l}\text { Biomass } \\
\text { wt. loss } \\
\text { (\%) }\end{array}$} & \multicolumn{3}{|c|}{ Component (\%) } \\
\hline & & CMCase & Xylanase & & & Glucan & Xylan & $\begin{array}{l}\text { Acid } \\
\text { insoluble } \\
\text { lignin }\end{array}$ \\
\hline 0 & 7.00 & 0.00 & 0.00 & $16.22 \pm 1.23$ & 0.00 & $\begin{array}{l}26.82 \\
\pm 1.57\end{array}$ & $\begin{array}{l}25.98 \\
\pm 2.68\end{array}$ & $\begin{array}{l}21.90 \pm \\
0.20\end{array}$ \\
\hline 5 & $\begin{array}{l}9.41 \\
\pm \\
0.03\end{array}$ & $\begin{array}{l}13.12 \pm \\
0.82\end{array}$ & $\begin{array}{l}135.60 \pm \\
2.29\end{array}$ & $50.23 \pm 2.09$ & $\begin{array}{l}30.43 \pm \\
0.33\end{array}$ & $\begin{array}{l}31.54 \\
\pm 1.90\end{array}$ & $\begin{array}{l}21.74 \\
\pm 0.62\end{array}$ & $\begin{array}{l}22.80 \pm \\
0.40\end{array}$ \\
\hline 10 & $\begin{array}{l}9.68 \\
\pm \\
0.07\end{array}$ & $\begin{array}{l}14.50 \pm \\
0.55\end{array}$ & $\begin{array}{l}199.63 \pm \\
7.57\end{array}$ & $41.17 \pm 2.02$ & $\begin{array}{l}32.53 \pm \\
0.38\end{array}$ & $\begin{array}{l}36.02 \\
\pm 0.80\end{array}$ & $\begin{array}{l}18.51 \\
\pm 1.71\end{array}$ & $\begin{array}{l}21.90 \pm \\
0.42\end{array}$ \\
\hline 20 & $\begin{array}{l}9.36 \\
\pm \\
0.11\end{array}$ & $\begin{array}{l}12.04 \pm \\
0.76\end{array}$ & $\begin{array}{l}148.90 \pm \\
5.01\end{array}$ & $55.50 \pm 0.74$ & $\begin{array}{l}33.91 \pm \\
0.21\end{array}$ & $\begin{array}{l}40.58 \\
\pm 2.09\end{array}$ & $\begin{array}{l}16.90 \\
\pm 0.11\end{array}$ & $\begin{array}{l}18.40 \pm \\
0.28\end{array}$ \\
\hline
\end{tabular}

Under the alkaline condition created by the strain P3, the high activity of xylanase was detected during the process of pretreatment with the maximum values of $199.63 \mathrm{U} \mathrm{g}^{-1}$ after $10 \mathrm{~d}$ of incubation (Table 1). After $20 \mathrm{~d}$ of pretreatment, xylanase activity was decline with the value of $148.90 \mathrm{U} \mathrm{g}^{-1}$. For CMCase activity, a similar trend was observed (Table 1). The highest level of xylanase activity observed here was higher than the activities of enzymes from other biomass-degrading Bacillus sp. strains under optimal conditions (Archana et al. 1997). Moreover, after pretreatment, the reducing sugar released in the culture broth was increased from $16.22 \mathrm{mg} \mathrm{g}^{-1}(0 \mathrm{~d})$ to $55.50 \mathrm{mg} \mathrm{g}^{-1}(20 \mathrm{~d})$ (Table 1). It was obvious that the cellulolytic enzymes produced in alkaline environment $(\mathrm{pH}$ 9.36-9.68) by the strain $\mathrm{P} 3 \mathrm{had}$ a significant effect on the release of xylose or glucose from corn stover.

\section{The weight losses and compositional variations of corn stover}

The weight losses of corn stover decayed by the strain P3 ranged from 30.43 to $33.91 \%$ with the increase of pretreatment time ( 5 to $20 \mathrm{~d}$ ). Compared to the corn stover pretreated for $5 \mathrm{~d}$, the weight loss increased by only $3.5 \%$ after $20 \mathrm{~d}$ of pretreatment, which indicated that there was slight consumption of raw materials with the extension of processing time. Moreover, the final weight loss caused by bacterial pretreatment in this study was much lower than the weight losses (38.60-52.80\%) caused by efficient biomass-degrading fungi (Saha et al. 2016). The result reported in this study demonstrated that the strain P3 has a great potential to pretreat the corn stover with less material loss.

Therefore, the effects of biopretreatment using the strain P3 on glucan, xylan and lignin contents of the pretreated corn stover were markedly different from non-pretreated corn stover (Table 1). The non- 
pretreated corn stover contained $26.82 \%$ glucan, $25.98 \%$ xylan and $21.90 \%$ acid insoluble lignin (Table 1 ), which were similar with the results obtained from previous research (Liu et at. 2013). After $5 \mathrm{~d}$ pretreatment by the strain P3, the corn stover had a xylan content of $21.74 \%$ showing a significant declined and the content of glucan was increased to $31.54 \%$ (Table 1), indicating the xylan (hemicellulose) was first decomposed by the high-content xylanase $\left(135.60 \mathrm{U} \mathrm{g}^{-1}\right)$ produced by the strain P3, thus, the cellulose would then be exposed to CMCase for further utilization (Polizeli et al. 2005). After $20 \mathrm{~d}$ of biopretreatment, the glucan content was significantly increased to $40.58 \%$, whereas the concentration of xylan was decreased markedly to $16.90 \%$ with slightly lignin removal. The ability to produce a large amount of xylanases from xylan present in hemicellulose has been previously observed in several Bacillus sp. strains (Sá-Pereira et al. 2002; Subramaniyan et al. 2000). Therefore, in this study, the exposure of glucan and decomposition of xylan demonstrated a satisfactory effect on the biopretreatment of xylan removal, which were the better results compared to the results obtained using xylanase-producing fungi and even using physicochemical methods to pretreat lignocellulosic biomass (Kuhar et al. 2008; Ravindran et al. 2017).

\section{Effects of biological pretreatment on enzymatic saccharification of corn stover}

For efficient hydrolysis of corn stover, commercial cellulase was used to conduct the enzymatic saccharification. The bacterial pretreated and non-pretreated corn stover exhibited significant degradability using $20 \mathrm{U} \mathrm{g}^{-1}$ commercial cellulase (Fig. 5). After $72 \mathrm{~h}$ of incubation, the 5,10 and $20 \mathrm{~d}$ pretreated corn stover samples were hydrolyzed by commercial cellulase, yielding 140.51, 144.06 and $203.97 \mathrm{mg} \mathrm{g}^{-1}$ reducing sugar, respectively, while the corresponding yield of reducing sugar released from non-pretreated corn stover was $130.87 \mathrm{mg} \mathrm{g}^{-1}$ (Fig. 5). Therefore, in this study, it was clear that the efficiencies of saccharification were significantly increased by $56 \%$ after $20 \mathrm{~d}$ of pretreatment, which is the highest increase rate of reducing sugar yield. Also, our result was superior to the previous results showed an increase of $32 \%$ reducing sugar yield after $60 \mathrm{~d}$ of incubation using fungal strains to pretreat lignocellulosic biomass (Taniguchi et al. 2005), thus, the strain P3 is a highly efficient bacterial candidate to improve saccharification efficiency of lignocellulosic material. Moreover, according to the results of Pearson correlation analysis (data not shown), the final yields of reducing sugar from pretreated and nonpretreated corn stover had a significant positive correlation with the content of glucan in corn stover $(\mathrm{P}<$ 0.05). Therefore, it can be inferred that the enzymatic hydrolysis was enhanced greatly after $20 \mathrm{~d}$ of pretreatment due to efficiently removal of the hemicellulosic fraction for exposing cellulose polymers to provide more accessible surface areas for commercial cellulase (Wan and Li 2010).

\section{Overall mass balance}

To generalize the complete process for carbohydrate degradation of corn stover pretreated by Bacillus sp. P3, a mass balance diagram was shown in Fig. 6. After $20 \mathrm{~d}$ pretreatment, the glucan content of corn stover was increased by $51 \%$ compared to that of non-pretreated corn stover, while the xylan content was decreased by $35 \%$. Moreover, the solid recovery was $66 \%$, which has met the standard of industrial 
production (Uppugundla et al. 2014). Our results indicated that the pretreated corn stover containing more accessible glucan could be applicable to the process of fermentation for biofuel production (Guo et al. 2017a). Furthermore, the total amount of reducing sugar released in the process of pretreatment and enzymatic saccharification was $20.58 \mathrm{~g}$ from per $100 \mathrm{~g}$ of pretreated corn stover, which was $57 \%$ higher than those of non-pretreated one. Although this study did not present the integrated technoeconomic evaluations in a process context for the bacterial pretreatment using the strain P3, it provided useful insights to ameliorate the pretreatments in an easier and greener way.

\section{Conclusions}

This study demonstrated an effective strategy to enhance the efficiency of enzymatic hydrolysis using Bacillus sp. P3 strain to pretreat the corn stover. After 20 d pretreatment of corn stover by the strain P3, the reducing sugar yield from the pretreated corn stover after enzymatic saccharification was increased by $56 \%$ compared to that from non-pretreated corn stover. Moreover, as a thermoalkalotolerant cellulolytic enzymes producing bacterium, the strain P3 and its enzymes can not only be utilized to pretreat biomass alone but can potentially be combined with other harsher methods to improve the cost-efficiency and ecofriendliness of industrial bioenergy productions.

\section{Declarations}

\section{Funding}

This work was supported by the Natural Sciences and Engineering Research Council of Canada to W. Q (grant number RGPIN-2017-05366), the China Scholarship Council to H. G (grant number 201506320044), and the Priority Academic Program Development of Jiangsu Higher Education Institutions (PAPD) Scholarship to Y. W.

\section{Contributions}

YW designed and conducted all experiments, collected data and prepared the manuscript. HG, MSR, XC and $Y L$ assisted with experiments and writing. WQ and JZ supervised the research and revised the manuscript. All authors have read and agreed to publish the final version of manuscript.

\section{Availability of data and materials}

The data and the materials are all available in this article and supplementary document file.

\section{Ethics approval and consent to participate}

Not applicable.

\section{Consent for publication}


Not applicable.

\section{Competing interests}

The authors declare no competing financial interests.

\section{Acknowledgement}

Not applicable

\section{References}

1. Akhtar MS, Saleem M, Akhtar MW (2001) Saccharification of lignocellulosic materials by the cellulases of Bacillus subtilis. Inter J Agri Biol 3(2): 199-202.

2. Arantes V, Saddler JN (2010) Access to cellulose limits the efficiency of enzymatic hydrolysis: the role of amorphogenesis. Biotechnol Biofuels 3(1), 4.

3. Archana A, Satyanarayana T (1997) Xylanase production by thermophilic Bacillus licheniformis A99 in solid-state fermentation. Enzyme Microbial Technol 21(1): 12-17.

4. Alvira P, Tomás-Pejó E, Ballesteros M, Negro M (2010) Pretreatment technologies for an efficient bioethanol production process based on enzymatic hydrolysis: a review. Bioresour Technol 101(13): 4851-4861.

5. Annamalai N, Thavasi R, Vijayalakshmi S, Balasubramanian T (2011) A novel thermostable and halostable carboxymethylcellulase from marine bacterium Bacillus licheniformis AU01. World $\mathrm{J}$ Microbiol Biotechnol 27(9): 2111-2115.

6. Bak JS, Kim MD, Choi IG, Kim KH (2010) Biological pretreatment of rice straw by fermenting with Dichomitus squalens. New Biotechnol 27(4): 424-434.

7. Annamalai N, Rajeswari MV, Balasubramanian T (2014) Enzymatic saccharification of pretreated rice straw by cellulase produced from Bacillus carboniphilus CAS 3 utilizing lignocellulosic wastes through statistical optimization. Biomass and Bioener 68: 151-160.

8. Bhalla A, Bansal N, Kumar S, Bischoff KM, Sani RK (2013) Improved lignocellulose conversion to biofuels with thermophilic bacteria and thermostable enzymes. Bioresour Technol 128: 751-759.

9. Bansod S, Dutta-Choudhary M, Srinivasan M, Rele M (1993) Xylanase active at high pH from an alkalotolerant Cephalosporium species. Biotechnol Letters 15(9): 965-970.

10. Chang S, Steinkraus K (1982) Lignocellulolytic enzymes produced by Volvariella volvacea, the edible straw mushroom. Appl and Environ Microbiol 43(2): 440-446.

11. Ferraz JLAA, Souza LO, Soares GA, Coutinho JP, de Oliveira JR, Aguiar-Oliveira E, Franco M (2017) Enzymatic saccharification of lignocellulosic residues using cellulolytic enzyme extract produced by Penicillium roqueforti ATCC 10110 cultivated on residue of yellow mombin fruit. Bioresour Technol 248:214-220. 
12. Guo H, Wu Y, Hong C, Chen H, Chen X, Zheng B, Jiang D, Qin W (2017a) Enhancing digestibility of Miscanthus using lignocellulolytic enzyme produced by Bacillus. Bioresour Technol 245: 1008-1015.

13. Guo H, Chen H, Fan L, Linklater A, Zheng B, Jiang D, Qin W (2017b) Enzymes produced by biomassdegrading bacteria can efficiently hydrolyze algal cell walls and facilitate lipid extraction. Renewable Energy 109: 195-201.

14. Himmel ME, Ding SY, Johnson DK, Adney WS, Nimlos MR, Brady JW, Foust TD (2007) Biomass recalcitrance: engineering plants and enzymes for biofuels production. Science 315(5813): 804-807.

15. Huser BA, Wuhrmann K, Zehnder AJ (1982) Methanothrix soehngenii gen. nov. sp. nov., a new acetotrophic non-hydrogen-oxidizing methane bacterium. Archives of Microbiol 132(1): 1-9.

16. Ibáñez $A B$, Bauer S (2014) Downscaled method using glass microfiber filters for the determination of Klason lignin and structural carbohydrates. Biomass Bioener 68: 75-81.

17. Keller FA, Hamilton JE, Nguyen QA (2003) Microbial pretreatment of biomass. Appl Biochem Biotechnol 105(1-3): 27.

18. Kim BK, Lee BH, Lee YJ, Jin IH, Chung CH, Lee JW (2009) Purification and characterization of carboxymethylcellulase isolated from a marine bacterium, Bacillus subtilis subsp. subtilis A-53. Enzyme Microbial Technol 44(6): 411-416.

19. Kirk TK, Cullen D (1998) Enzymology and molecular genetics of wood degradation by white-rot fungi. Environmentally Friendly Technologies for the Pulp and Paper Industry. Wiley, New York pp 273-307.

20. Kohli U, Nigam P, Singh D, Chaudhary K (2001) Thermostable, alkalophilic and cellulase free xylanase production by Thermoactinomyces thalophilus subgroup C. Enzyme Microbial Technol 28(7): 606-610.

21. Kuhar S, Nair LM, Kuhad RC (2008) Pretreatment of lignocellulosic material with fungi capable of higher lignin degradation and lower carbohydrate degradation improves substrate acid hydrolysis and the eventual conversion to ethanol. Canadian J Microbiol 54(4): 305-313.

22. Kumar R, Mago G, Balan V, Wyman CE (2009) Physical and chemical characterizations of corn stover and poplar solids resulting from leading pretreatment technologies. Bioresour Technol 100(17): 3948-3962.

23. Lee YJ, Kim BK, Lee BH, Jo KI, Lee NK, Chung CH, Lee YC, Lee JW (2008) Purification and characterization of cellulase produced by Bacillus amyoliquefaciens DL-3 utilizing rice hull. Bioresour Technol 99(2): 378-386.

24. Leyva A, Quintana A, Sánchez M, Rodríguez EN, Cremata J, Sánchez JC (2008) Rapid and sensitive anthrone-sulfuric acid assay in microplate format to quantify carbohydrate in biopharmaceutical products: Method development and validation. Biologicals 36(2): 134-141.

25. Lin C, Shen Z, Qin W (2017) Characterization of xylanase and cellulase produced by a newly isolated Aspergillus fumigatus N2 and its efficient saccharification of barley straw. Appl Biochem Biotechnol 182(2):559-569.

26. Liu C, Hao Y, Jiang J, Liu W (2017) Valorization of untreated rice bran towards bioflocculant using a lignocellulose-degrading strain and its use in microalgal biomass harvest. Biotechnol Biofuels 10, 90. 
27. Liu C, van der Heide E, Wang H, Li B, Yu G, Mu X (2013) Alkaline twin-screw extrusion pretreatment for fermentable sugar production. Biotechnol Biofuels 6(1), 97

28. Lynd LR, Weimer P J, Van Zyl WH, Pretorius IS (2002) Microbial cellulose utilization: fundamentals and biotechnology. Microbiol Molecular Biol Rev 66(3): 506-577.

29. Maki M, Leung KT, Qin W (2009) The prospects of cellulase-producing bacteria for the bioconversion of lignocellulosic biomass. Inter J Biol Sci 5(5): 500-516.

30. Miller GL (1959) Use of dinitrosalicylic acid reagent for determination of reducing sugar. Analytical Chem 31(3): 426-428.

31. Papavizas G, Dunn M, Lewis, Beagle-Ristaino J (1984) Liquid fermentation technology for experimental production of biocontrol fungi. Phytopathol 74(10): 1171-1175.

32. Pérez J, Munoz-Dorado J, de la Rubia T, Martinez J (2002) Biodegradation and biological treatments of cellulose, hemicellulose and lignin: an overview. Inter Microbiol 5(2): 53-63.

33. Polizeli M, Rizzatti A, Monti R, Terenzi H, Jorge JA, Amorim D (2005) Xylanases from fungi: properties and industrial applications. Appl Microbiol Biotechnol 67(5): 577-591.

34. Ravindran R, Jaiswal S, Abu-Ghannam N, Jaiswal AKA (2017) Comparative analysis of pretreatment strategies on the properties and hydrolysis of Brewers' spent grain. Bioresour Technol 248: 272-279.

35. Sangrila S, Maiti T (2013) Cellulase production by bacteria: a review. British Microbiol Res J 3(3): 235-258.

36. Shrestha P, Ibáñez AB, Bauer S, Glassman SI, Szaro TM, Bruns TD, Taylor JW (2015) Fungi isolated from Miscanthus and sugarcane: biomass conversion, fungal enzymes, and hydrolysis of plant cell wall polymers. Biotechnol Biofuels 8(1), 38.

37. Singh R, Varma A, Laxman RS, Rao M (2009) Hydrolysis of cellulose derived from steam exploded bagasse by Penicillium cellulases: comparison with commercial cellulase. Bioresour Technol 100(24): 6679-6681.

38. Sadhu S, Saha P, Sen SK, Mayilraj S, Maiti TK (2013) Production, purification and characterization of a novel thermotolerant endoglucanase (CMCase) from Bacillus strain isolated from cow dung. SpringerPlus 2: 10.

39. Saha BC, Qureshi N, Kennedy GJ, Cotta MA (2016) Biological pretreatment of corn stover with whiterot fungus for improved enzymatic hydrolysis. Inter Biodeterioration Biodegradation 109: 29-35.

40. Sá-Pereira P, Mesquita A, Duarte JC, Barros MRA (2002) Costa-Ferreira, M., Rapid production of thermostable cellulase-free xylanase by a strain of Bacillus subtilis and its properties. Enzyme Microbial Technol 30(7): 924-933.

41. Saratale GD, Oh SE (2011) Production of thermotolerant and alkalotolerant cellulolytic enzymes by isolated Nocardiopsis sp. KNU. Biodegradation 22(5): 905-919.

42. Schallmey M, Singh A, Ward OP (2004) Developments in the use of Bacillus species for industrial production. Canadian J Microbiol 50(1): 1-17. 
43. Subramaniyan S, Prema P (2000) Cellulase-free xylanases from Bacillus and other microorganisms. FEMS Microbiol Letters 183(1): 1-7.

44. Taniguchi M, Suzuki H, Watanabe D, Sakai K, Hoshino K, Tanaka T (2005) Evaluation of pretreatment with Pleurotus ostreatus for enzymatic hydrolysis of rice straw. J Biosci Bioeng 100(6): 637-643.

45. Tomoda M (1963) Colorimetric determination of pentoses. IV. determination with orcinol reagent. Chemical Pharma Bull 11(6): 809-812.

46. Uppugundla N, da Costa Sousa L, Chundawat SP, Yu X, Simmons B, Singh S, Gao X, Kumar R, Wyman CE, Dale BE (2014) A comparative study of ethanol production using dilute acid, ionic liquid and AFEX'M pretreated corn stover. Biotechnol Biofuels 7(1), 72.

47. Wan C, Li Y (2010) Microbial pretreatment of corn stover with Ceriporiopsis subvermispora for enzymatic hydrolysis and ethanol production. Bioresour Technol 101(16): 6398-6403.

48. Wang FQ, Xie H, Chen W, Wang ET, Du FG, Song AD (2013) Biological pretreatment of corn stover with ligninolytic enzyme for high efficient enzymatic hydrolysis. Bioresour Technol 144: 572-578.

49. Wilson DB (2009) Cellulases and biofuels. Current Opinion Biotechnol 20(3): 295-299.

50. Xiao Z, Zhang X, Gregg DJ, Saddler JN (2004) Effects of sugar inhibition on cellulases and $\beta$ glucosidase during enzymatic hydrolysis of softwood substrates, Proceedings of the twenty-fifth symposium on biotechnology for fuels and chemicals, Held May 4-7, 2003, in Breckenridge, CO, 2004; Springer pp 1115-1126.

51. Yeoman CJ, Han Y, Dodd D, Schroeder CM, Mackie RI, Cann IK (2010) Thermostable enzymes as biocatalysts in the biofuel industry. Advances Appl Microbiol 70: 1-55.

52. Zhao L, Cao GL, Wang AJ, Ren HY, Dong D, Liu ZN, Guan XY, Xu CJ, Ren NQ (2012) Fungal pretreatment of cornstalk with Phanerochaete chrysosporium for enhancing enzymatic saccharification and hydrogen production. Bioresour Technol 114: 365-369.

\section{Figures}




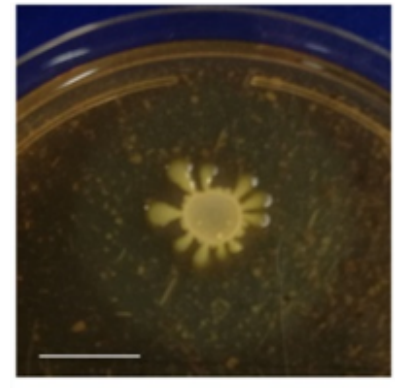

Agave

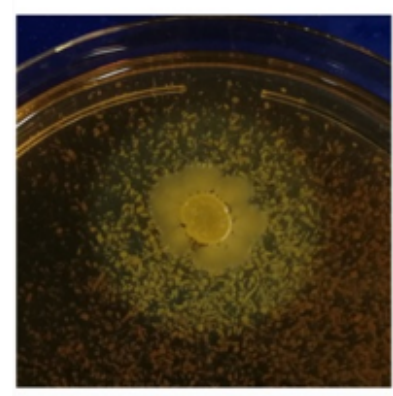

Wood

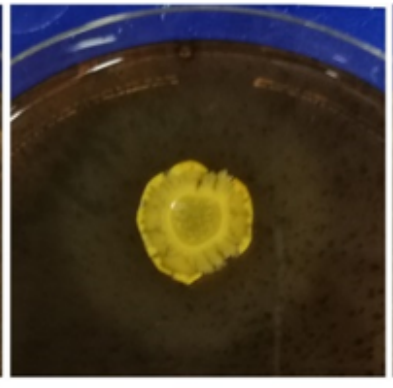

Algae

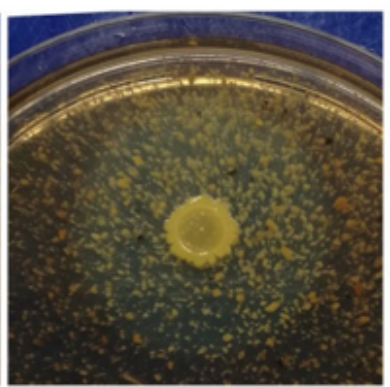

Pine

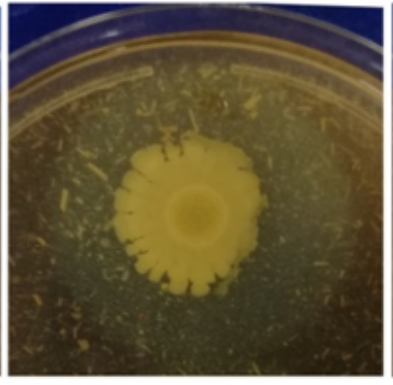

Corn

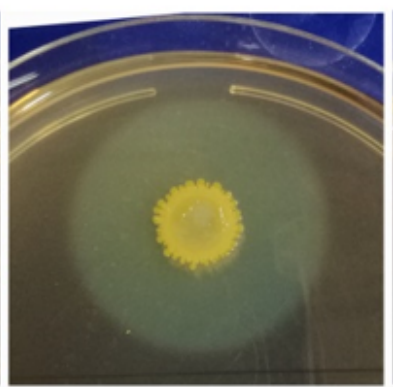

CMC

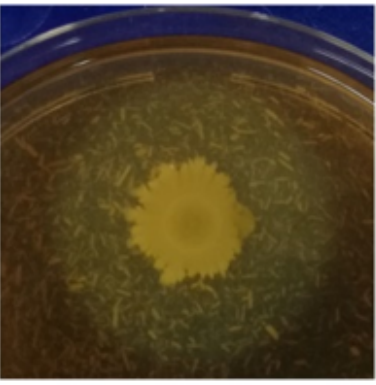

Mis

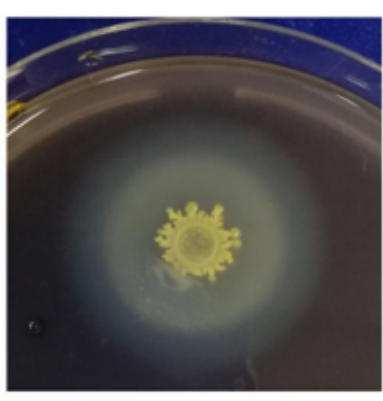

Xylan

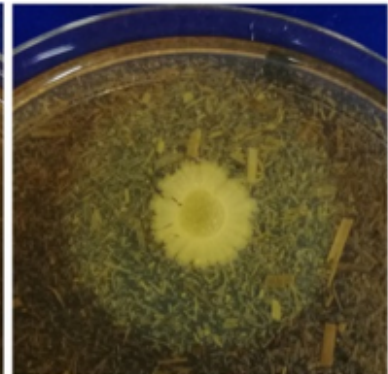

Wheat

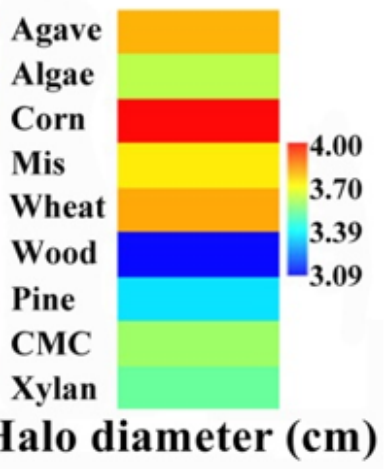

Figure 1

The halo diameters (cm) of Bacillus sp. P3 using different biomasses, CMC and xylan as carbon source were measured by Gram's iodine staining. The hydrolysis abilities were exhibited and compared by matrix plot. 


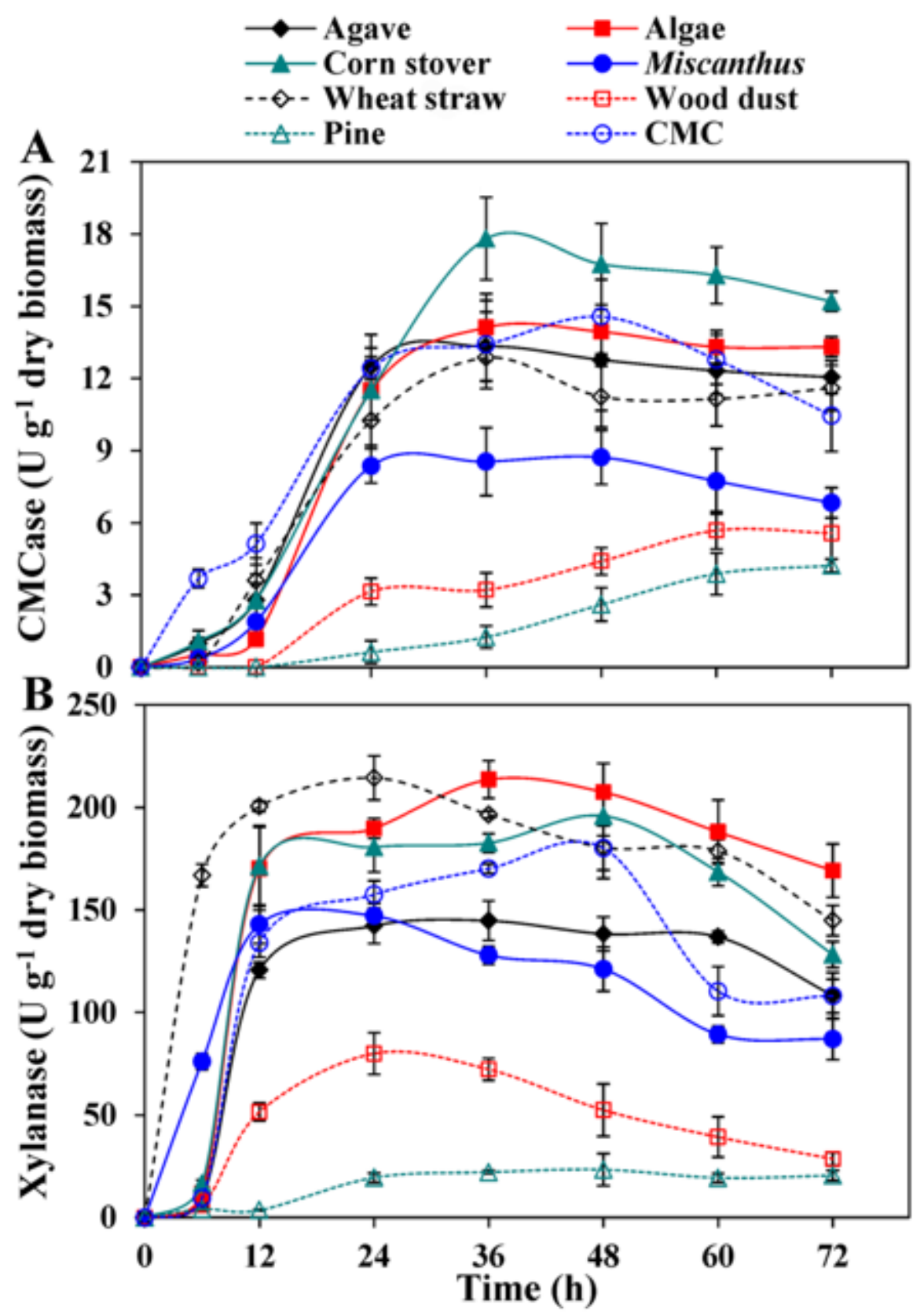

Figure 2

CMCase (A) and xylanase (B) activities of Bacillus sp. P3 cultivated with different biomasses and CMC. Bars indicate the standard deviation $(n=3)$. 


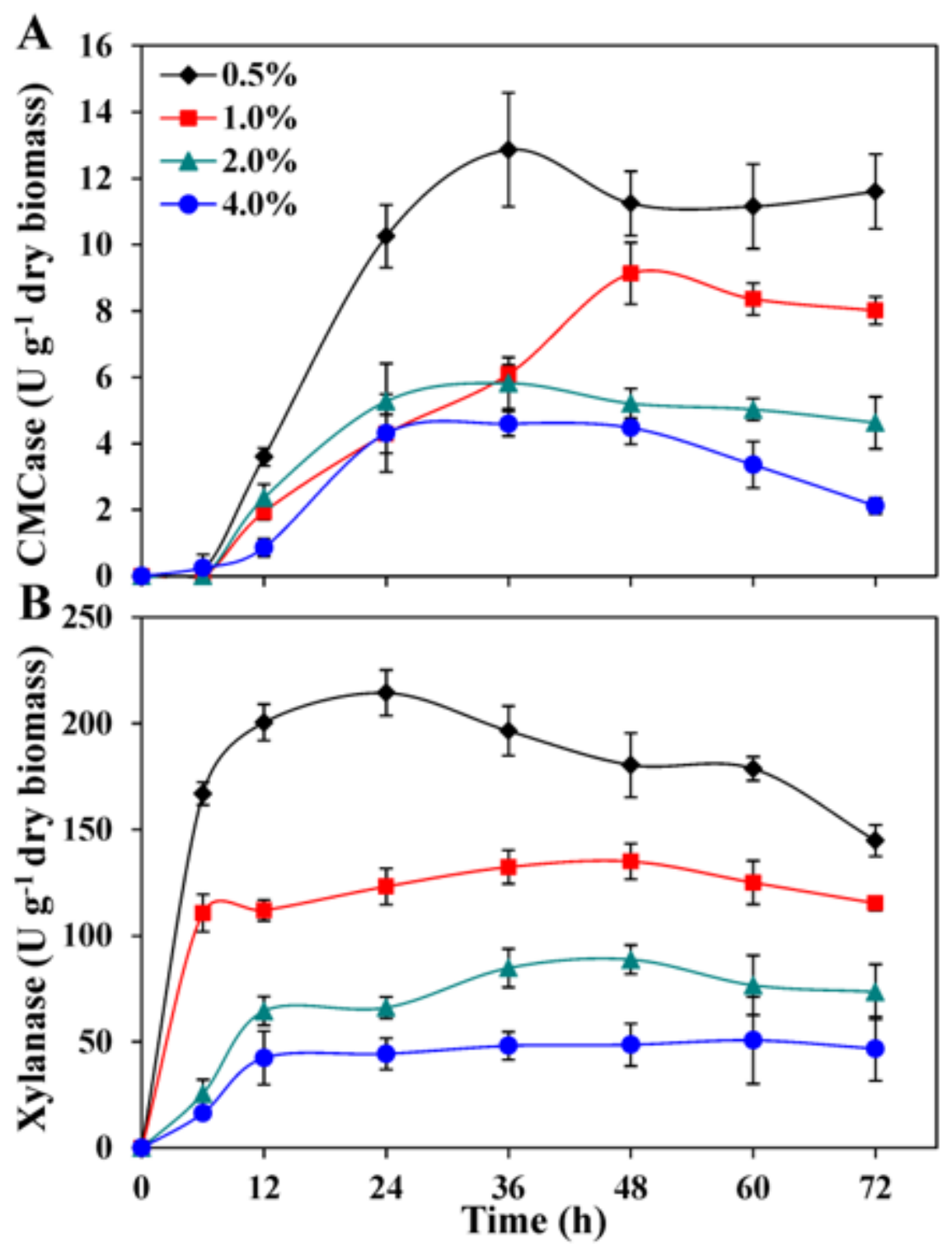

Figure 3

CMCase (A) and xylanase (B) activities of Bacillus sp. P3 using corn stover as substrate with different additions. Bars indicate the standard deviation $(n=3)$. 

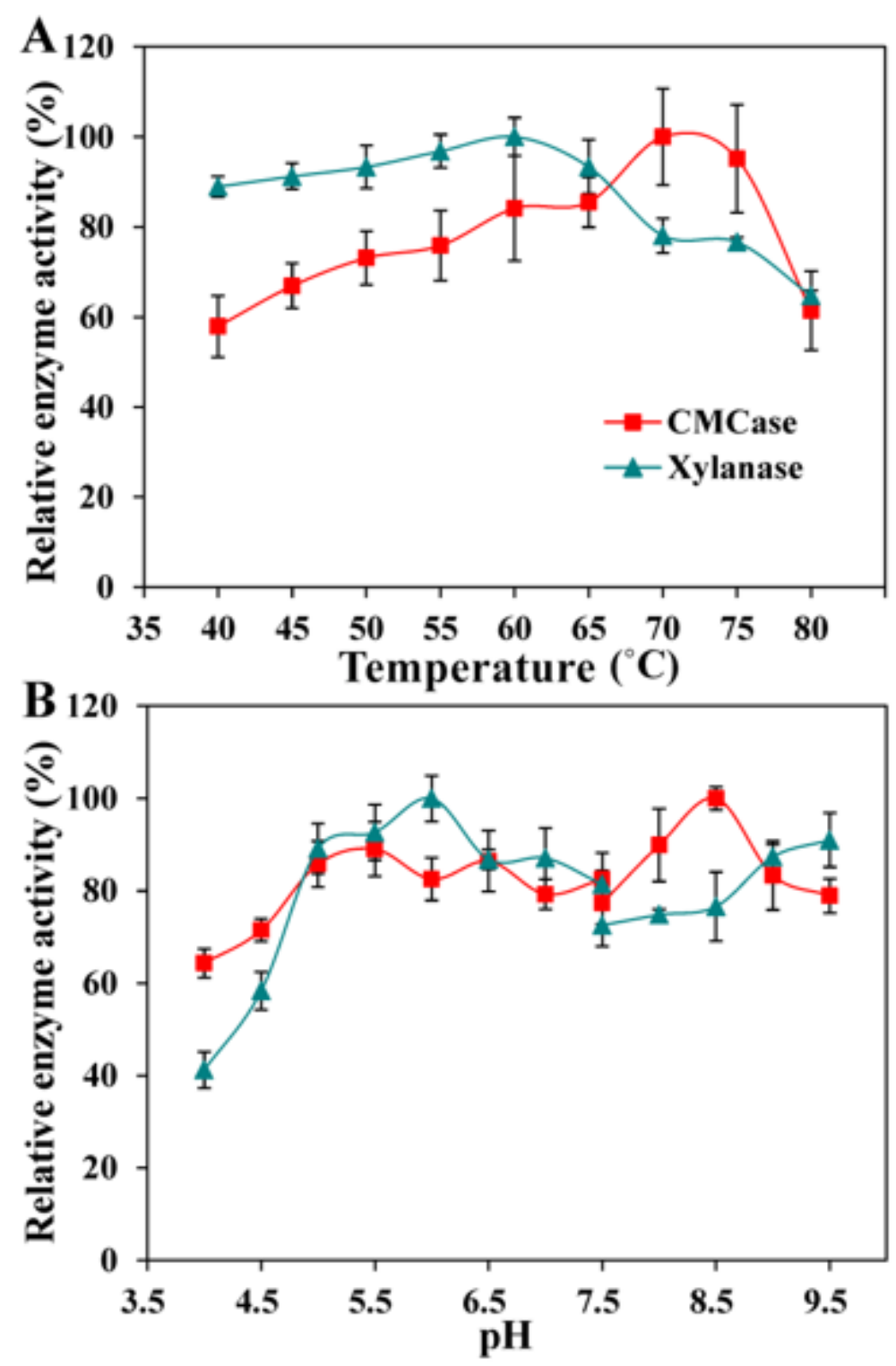

Figure 4

Effects of different temperatures $(\mathrm{A})$ and $\mathrm{pH}(\mathrm{B})$ on enzymatic activity (\%) determined by incubating the crude enzymes with $\mathrm{CMC}$ or xylan for $30 \mathrm{~min}$. Bars indicate the standard deviation $(n=3)$. 


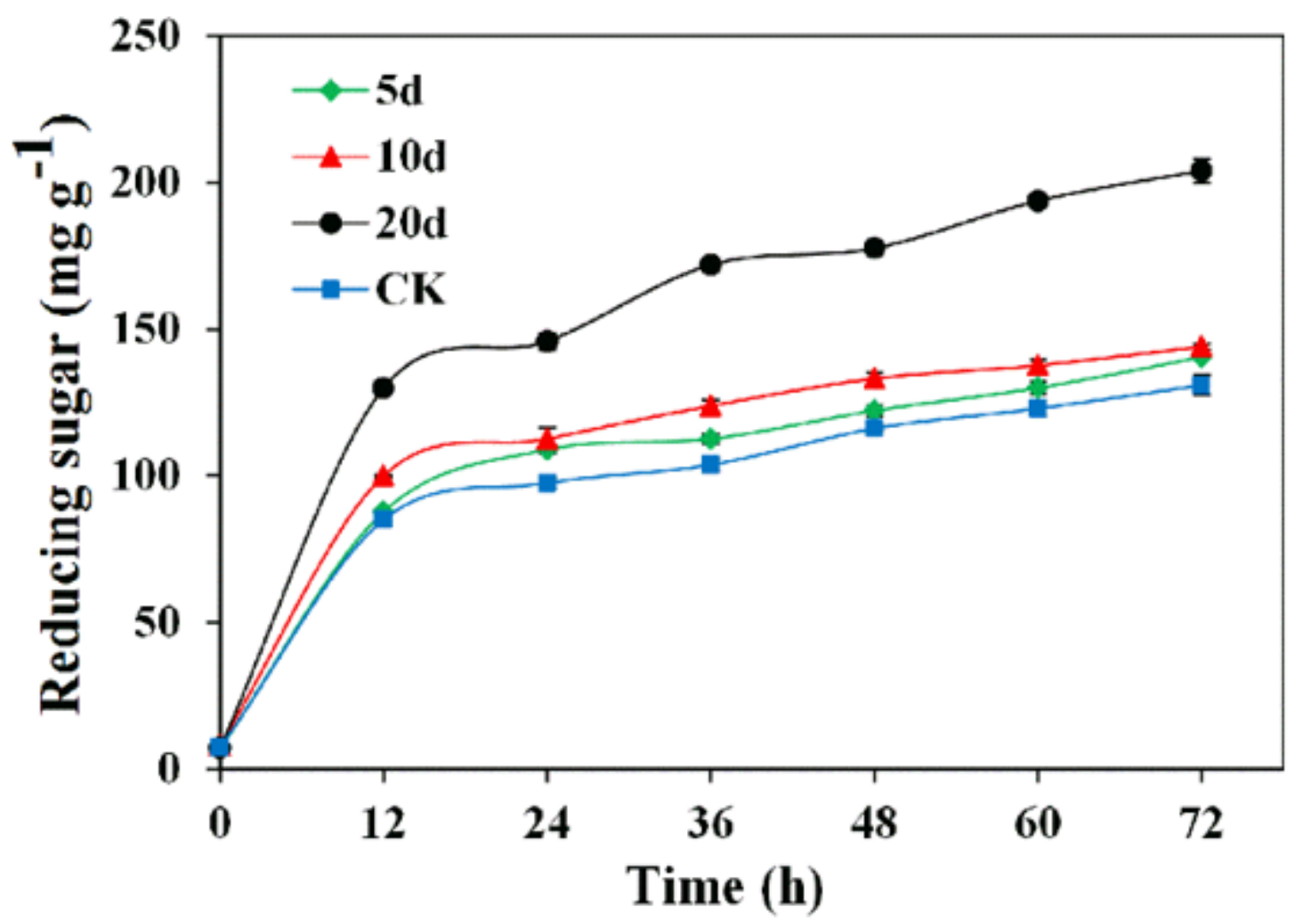

Figure 5

Saccharification of 0 (CK, non-pretreated corn stover), 5, 10 and $20 \mathrm{~d}$-pretreated corn stovers using commercial cellulases. Bars indicate the standard deviation $(n=3)$.

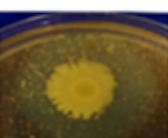

Screening lignocellulolytic enzymes-producing bacteria using Gram's iodine staining
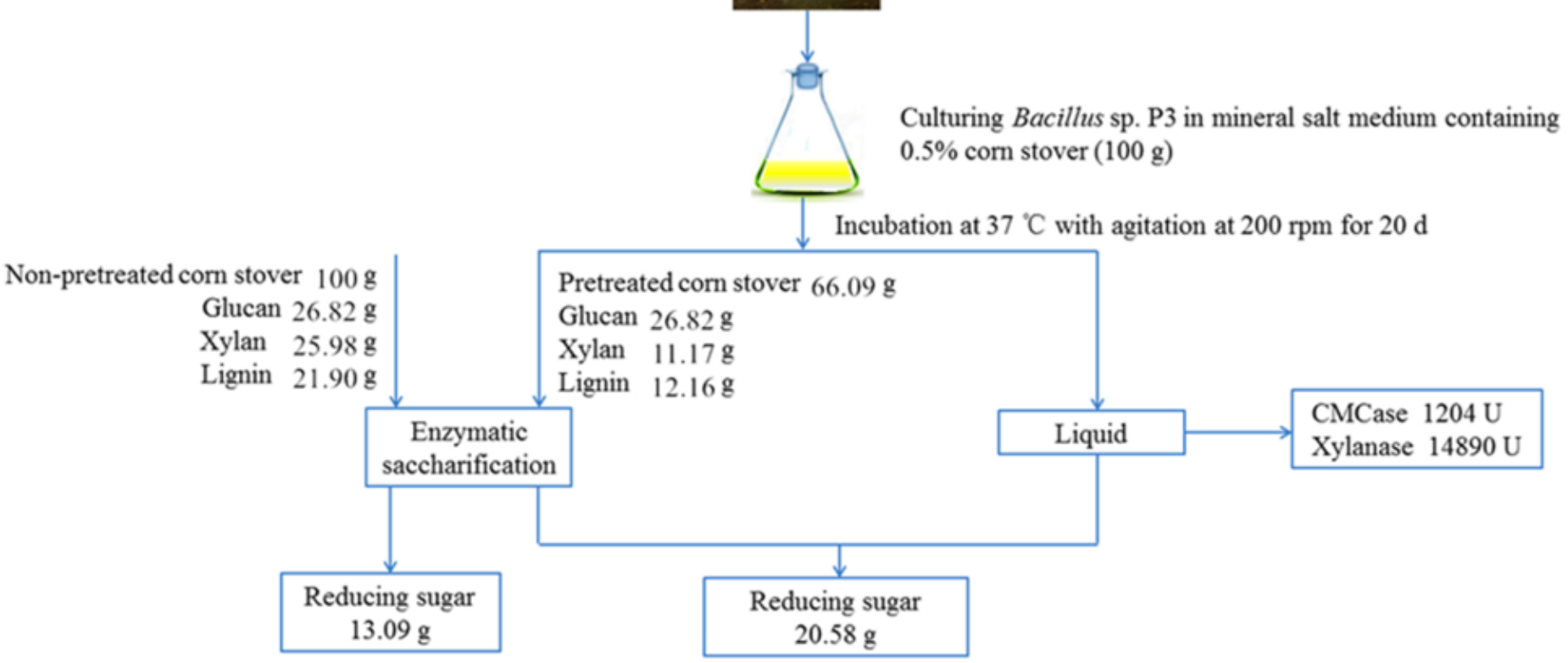

Figure 6 
Flow chart summarizing the effects of Bacillus sp. P3 on cellulolytic enzymes production, xylan decomposition, lignin removal and enzymatic saccharification of corn stover.

\section{Supplementary Files}

This is a list of supplementary files associated with this preprint. Click to download.

- GraphicalAbstract1.docx

- SupplementaryMaterial.docx 